\title{
EDITORIAL: \\ Social Work and Service-Learning in the Age of Competency-based Education
}

\author{
Lisa E. McGuire \\ Virginia Majewski \\ Special Issue Co-editors
}

We are pleased and proud to have served as Guest Editors for this special issue of Advances in Social Work focusing on "Social Work and Service-Learning in the Age of Competency-based Education.” This compilation of peer-reviewed articles provides a timely update to the growing literature on service-learning in social work education. Each article provides a snapshot of how individual faculty and their respective programs have embraced service-learning to enable students to achieve mastery of the competencies as articulated in the Council of Social Work Education's (CSWE, 2008) Educational Policy and Accreditation Standards (EPAS). As a whole, this issue demonstrates how the 2008 EPAS challenges faculty to be innovative in preparing students for professional practice. With each article as a snapshot, the issue itself provides a panorama of how servicelearning pedagogy provides multiple opportunities for social work education to operationalize and assess the competencies necessary for professional practice in the current dynamic practice environment.

The special issue grew from a workshop held in Indianapolis in May of 2010 entitled Assessing Professional Competencies through Service-learning: A Dialogue and Think Tank, or the Think Tank from here forward. The Think Tank brought together over 50 faculty members from around the nation who were using or interested in implementing service-learning pedagogy in their courses. The Think Tank began with the opening plenary delivered by internationally-recognized service-learning scholar, Dr. Robert G. Bringle, who presented Service-learning, Social Justice and Assessing Competencies: An Overview. The group then engaged in a passionate dialogue exploring the social justice mandate of the profession and basic issues of competency-based education. Participants voiced concerns that competency-based education in social work, as articulated by the EPAS (CSWE, 2008), might limit faculty members' ability to be creative with experiential pedagogies such as service-learning. There was also concern that the emphasis on assessment might dilute the professional purpose of promoting social and economic justice. These concerns were not surprising given that service-learning pedagogy is part of a larger movement to facilitate the civic engagement of higher education (Boyer, 1990; Colby, Ehrlich, Beaumont, \& Stephens, 2003) and that faculty members who are interested in service-learning are likely to highly value civic involvement for themselves and their students. Feeling that a competency-based approach was leading to the "rubric-ization" of social work education, and away from the mission

Lisa E. McGuire, Ph.D., is an Associate Professor and Interim Director of the BSW Program and Virginia Majewski is a Professor and Associate Dean, both in the Indiana University School of Social Work at the Indianapolis campus. They would like to thank Shawn Hensley for her editing help and Mary Lindop for her help in organizing the THINK TANK workshop.

Copyright (c) 2011 Advances in Social Work Vol. 12 No. 1 (Spring 2011), i-vii 
of social justice, the first morning of the dialogue ended on a somewhat somber, if thoughtful, note.

In the afternoon, faculty members grouped themselves around selected EPAS (CSWE, 2008) competencies including diversity, policy and human behavior and the social environment (HBSE). Social work faculty proved their resilience as they began to share how they had integrated service-learning activities to provide learning experiences for students in these areas. The synergy created in these discussions refocused faculty members on the competencies that they had watched their students develop through their service-learning experiences. Discussions continued through dinner and participants regained their resolve to find the fit between the requisite competencies, service-learning pedagogy, and assessment.

With the second plenary from Dr. Patti Clayton entitled Cultivating Competencies through Integrating Critical Reflection and Assessment, issues began to come together. Service-learning has always emphasized reflection as a requirement for high-quality pedagogy (Eyler, 2000; Eyler \& Giles, 1999) and Dr. Clayton's presentation provided a roadmap for utilizing reflection as a tool to not just document and deepen, but also assess, learning (Ash \& Clayton, 2004). Providing examples from her consulting work, she demonstrated how using rubrics in a positive manner could "Bloom-ify" (Bloom, 1956) the EPAS (CSWE, 2008) practice behaviors, facilitating students in moving from the lower levels of "identify and explain" to the high levels of "apply, analyze and evaluate." The critical thinking required in reflection was demonstrated to provide the means to both assist students in deepening their learning while also demonstrating competence. Participants went away from this session energized by the possibilities of utilizing structured, critical reflection to not only evidence the impact of service-learning pedagogy, but to also demonstrate a wide range of competencies.

The Think Tank certainly challenged and inspired participants to continue their exploration of service-learning pedagogy and encapsulate their experiences in many of the articles in this special issue. Burke's (2011) conceptual exploration of civic education and social work is an excellent reflection of issues raised in the first session of the Think Tank, while Twill, Elpers, and Lay (2011) provide a demonstration of using a structured reflection assignment to move students forward in Bloom's (1956) taxonomy with HBSE content. Lucas-Darby (2011) offers an innovative example of how social work education may focus students on aspects in the physical environment, moving the profession forward to consider important issues of energy conservation and recycling as emerging social issues.

Combined with the contributions of other scholars who have also explored servicelearning pedagogy, this issue includes a broad array of thinking around service-learning in the age of competency-based education in social work. The issue begins with a review of social work and service-learning provided by Phillips (2011). Building on her previous article (Phillips, 2007), she provides a summary of the "state of the art" regarding service-learning, both in higher education and social work education. Focusing on the dearth of conceptual clarity around service-learning in social work education, she proposes critical questions and some tentative ways to ameliorate the risks of losing the 
civic engagement focus of service-learning in a context of behavioral assessment of competencies. Burke (2011) continues the exploration of the civic engagement aspect of service-learning with a thought-provoking review of concepts such as democracy and professionalism as they relate to the civic education of social work students. Next, Nino, Cuevas, and Loya (2011) present an example of how one social work program has created a community-based agency which provides an array of services, utilizing the service-learning volunteers along with practicum students to address the unmet needs of the community. This innovative endeavor models civic involvement by social work faculty and provides opportunities for transformative learning for students.

The remaining articles provide exemplars of the utilization of service-learning pedagogy in ways that are particularly important to current social work practice. In fact, if one were to make of list of emerging challenges for social work education, it would certainly include issues such as the need to become globally and culturally competent, the importance of linking theory to evidence-based practices, the benefits of interdisciplinary collaborations, the challenge to prepare students to meet the growing need for competencies in gerontology, and the mandate to move to a greener way of community life to protect the environment for current and future generations. An example of utilizing service-learning pedagogy is presented on each of these important topics.

As mentioned earlier, Twill, Elpers, and Lay (2011) present an example of how a service-learning experience may provide evidence of mastery of competency/practice behaviors designated for HBSE (CSWE, 2008). Social work education programs have traditionally been organized around content areas and the shift to competencies may be challenging for faculty who teach theory. Service-learning pedagogy, including reflections structured around the identified practice behaviors, provides a framework for the shift, as well as a way to provide evidence of student mastery.

The next two articles provide examples of international service-learning (Ericson, 2011) and interdisciplinary collaboration to develop cross-cultural knowledge (Belliveau, 2011). Ericson (2011) highlights the opportunities and challenges of an international service-learning course to develop competencies/practice behaviors in human rights as well as diversity and difference. Utilizing quantitative survey and qualitative journal data, students demonstrated increases in their self-reported competency and the gains seemed to continue beyond the trip itself. Belliveau (2011) addresses similar competencies around human rights and social justice as well as diversity and difference in a crosscultural project much closer to home. This example is powerful in illustrating an interdisciplinary collaboration with the university Spanish language department to provide an immersive experience with Latino parents in a school setting. The planned activity presented serendipitous opportunities for students to experience how the sociopolitical context of immigrant families, as well as language differences, creates barriers, as well as opportunities, for parents and children alike.

The final two articles focus on emerging issues that face our country, as well as the planet, and are those which future social workers will need to address, long after social work educators of today have completed their careers. As older adults are becoming increasingly represented in the American population, as well as in the client populations 
served by social workers, Jones (2011) provides an example of service-learning to expose students to this underserved population and explore attitudes toward aging. Encouraging students to reflect upon their own aging process while building competencies measured by the Geriatric Social Work Competency Scale II (Damron-Rodriquez, 2006), students demonstrated gains on all 4 subscales of the tool, which supports previous research of the utilization of service-learning in geriatric settings. And finally, Lucas-Darby (2011) focuses attention on the protection of the environment, supporting sustainability of the environment as a basic human right. A service-learning assignment in a community practice class resulted in three diverse projects which allowed opportunities for students to build competency in multiple areas of the advancement of human rights, community context and community practice.

As the articles discussed above were reviewed, edited and made ready for final publication, the editors identified overarching themes that transcend the individual contributions to the literature on social work and service-learning as related to the current context of competency-based assessment in higher education. The movement to assess learning outcomes in higher education has come from both regional accrediting bodies as well as professional accrediting organizations such as CSWE (Holloway, 2008), which provide the broader context for this analysis. The first theme relates to the importance of civic engagement and the mission of social work education. Although much of the emphasis in preparing for CSWE accreditation/reaffirmation seems focused on curriculum and competencies/practice behaviors, the new standards also highlight a School/Program's mission and the need to provide evidence that the mission is being met. Given that the professional purpose focuses on issues of social and economic justice, respect for diversity, and elimination of poverty and oppression (NASW, 2008; IFSW, n.d.), one would be hard-pressed to find a social work program whose mission did not focus on these issues. Service-learning pedagogy, with the emphasis on civic engagement and services to vulnerable populations, may provide powerful evidence that Schools/Programs are indeed meeting their missions. These efforts of individual faculty members in implementing this pedagogy may be thus viewed as part of a School/Program's strategy to demonstrate Educational Policy 1.0 - Program Mission and Goals (CSWE, 2008). In addition, the efforts of a social work program to implement service-learning and foster civic engagement become part of the overall college/university strategy for civic engagement, which is now required for regional accreditation as well.

As part of the clear emphasis on program mission and goals, EPAS (CSWE, 2008) also has added a standard to specifically address program context. Holloway (2008) identifies that "(a)ttention to context is found throughout the new standards" (p. 3). The Educational Policy 1.2 Program Context states that "(p)rograms are further influenced by their historical, political, economic, social, cultural, demographic, and global contexts and by the ways they elect to engage these factors" (CSWE, 2008, p. 2). Each of the specific examples of service-learning courses in this volume provides opportunities to identify factors particular to the college/university context (e.g., traditional age undergraduate students working with older adults, students from homogeneous communities participating in an international experience, students developing services for 
a changing demographic, etc.). These unique opportunities grow directly from the local needs of the area and provide evidence that Schools/Programs are indeed responding to their university mission and setting in providing social work education to students.

And finally, and perhaps most importantly, service-learning provides the opportunity for an emphasis on the process of learning over time. As discussed by Phillips (2011) and Nino, Cuevas, and Loya (2011), as well as by other scholars, service-learning pedagogy is often utilized by faculty in the beginning of a student's academic career. This has multiple benefits for students in professions such as education, nursing and social work. These include allowing for career exploration, ensuring that a career is a good fit and introducing some of the major challenges and themes that will be explored throughout the student's academic program. Given that EPAS (CSWE, 2008) focuses attention on the outcome assessment for student competencies and practice behaviors at the end of their academic career, service-learning creates an opportunity to focus on the journey toward competency, through its emphasis on early experience and reflection.

It is clear that many service-learning courses have the potential to generate direct evidence of the achievement of specific competencies and practice behaviors. In addition to summative assessment, the opportunity to apply complex content on topics as farranging as HBSE theory, community practice, and cultural competency to specific situations in a service-learning course may only serve to better prepare students for demonstrating competency in the field, where it is appropriately required to be assessed. The requisite emphasis on the development of structured, critical reflection becomes instrumental in describing, deepening, and documenting learning (Ash \& Clayton, 2004). Highly developed skills of structured, critical reflection will be necessary for students to identify and provide evidence for the wide array of competencies and practice behaviors from their practicum experiences. Although field is certainly the "signature pedagogy" (Shulman, 2005) of social work, skills in reflection are arguably necessary for students to be able to maximize their learning and integrate classroom content and the field activities for competent practice. Well-designed service-learning courses have the potential to be a powerful tool for social work educators to meet the expectations of professional education as well as the civic mission of the profession itself.

\section{References}

Ash, S., \& Clayton, P. (2004). The articulated learning: An approach to reflection and assessment. Innovative Higher Education, 29(2), 137-154.

Belliveau, M. (2011). Interdisciplinary service learning: Building student competencies through the cross-cultural parent groups project. Advances in Social Work, 12(1), 7993.

Bloom, B. S. (1956). Taxonomy of educational objectives: The classification of educational goals. Handbook I: Cognitive Domain. New York: David McKay Company.

Boyer, E. L. (1990). Scholarship reconsidered: Priorities for the professorate. Menlo Park, CA: The Carnegie Foundation for the Advancement of Teaching. 
Burke, T. K. (2011). Civic professionalism: Using service learning to educate social work students as citizens. Advances in Social Work, 12(1), 21-32.

Colby, A., Ehrlich, T., Beaumont, E., \& Stephens, J. (2003). Educating citizens: Preparing America's undergraduates for lives of moral and civic responsibility. San Francisco, CA: Jossey-Bass.

Council on Social Work Education. (2008). Educational policy and accreditation standards. Retrieved from http://www.cswe.org/File.aspx?id=13780

Damron-Rodriguez, J. A. (2006). Moving forward: Developing geriatric social work competencies. In B. Berkman (Ed.), Handbook of social work in health and aging (pp. 1051-1068). New York: Oxford Press.

Ericson, C. B. (2011). Pura vida with a purpose: Energizing engagement with human rights through service learning. Advances in Social Work, 12(1), 63-78.

Eyler, J. (2000). What do we most need to know about the impact of service-learning on student learning? Michigan Journal of Community Service Learning, Special Issue, Fall, 11-17.

Eyler, J., \& Giles, D. E. (1999). Where’s the learning in service-learning? San Francisco, CA: Jossey-Bass.

Holloway, S. (2008). Some suggestions on educational program assessment and continuous program improvement: Revised for the 2008 EPAS. Silver Spring, MD: Council on Social Work Education.

International Federation of Social Workers (IFSW). (n.d.) Retrieved from http://www.ifsw.org/

Jones, S. H. (2011). Life is experienced until we die: Effects of service learning on gerontology competencies and attitudes toward aging. Advances in Social Work, 12(1), 94-112.

Lucas-Darby, E. T. (2011). The new color is green: Social work practice and service learning. Advances in Social Work, 12(1), 113-125.

National Association of Social Workers (NASW). (2008). Code of ethics of the national association of social workers. Retrieved from http://www.socialworkers.org/pubs/code/code.asp

Nino, M., Cuevas, M., \& Loya. M. (2011). Transformational effects of service learning in a university developed community based agency. Advances in Social Work, 12(1), 33-48.

Phillips, A. (2007). Service learning and social work education: A natural but tenuous connection. In M. Nadel, V. Majewski, \& M. Sullivan-Cosetti (Eds.), Social work and service learning: Partnerships for social justice (pp. 3-19). Lanham, MD: Rowman \& Littlefield. 
Phillips, A. (2011). Service learning and social work competency based education: A 'goodness of fit'? Advances in Social Work, 12(1), 1-20.

Shulman, L. (2005). Signature pedagogies in the professions. Daedalus, 134(3), 52-60.

Twill, S., Elpers, K., \& Lay, K. (2011). Achieving HBSE competencies through service learning. Advances in Social Work, 12(1), 49-62.

\section{Author Note:}

Direct correspondence to Lisa McGuire, Ph.D., Indiana University School of Social Work, 902 W. New York Street, Indianapolis, IN 46202. Email: lmcguir@iupui.edu 